\title{
Research on the Influence of the Brand Origin Image on Consumer Purchase Intention- an Empirical Study Based on the Laptop Student Market
}

\author{
Ze Gao
}

\author{
School of Business Administration, Jilin Engineering Normal University, Changchun, P.R.China \\ 19877721@qq.com
}

\begin{abstract}
Keywords: Country of origin; Country of origin effect; Purchase intention
\end{abstract}
\begin{abstract}
In today's society, with the great enrichment of material life, the vast majority of products are oversupplied, and the differences between products are becoming smaller and smaller with the progress of production technology. Under such circumstances, if the enterprise wants to survive, it is far from enough to rely solely on the competition of the product itself. Competition between enterprises has evolved into competition among brands in the modern society. The country-of-origin image is an important part of the brand. It is the perception and attitude of consumers for a certain brand, which directly affects the purchase behavior of consumers. Therefore, in recent years, the place of origin image is becoming a hot issue in the brand. Both the practical and theoretical circles have made a lot of discussions on the composition and influencing factors of brand image. Among the factors influencing brand image, a new concept in marketing-country of origin image is attracting widespread attention.
\end{abstract}

\section{Introduction}

With the development of international trade, the analysis and study of the country of origin have arisen. Since it was put forward and noticed by scholars at home and abroad, it has been a hot issue in international marketing. The country of origin image has received long-term attention from western scholars. With the controversy over the concept of "made in China" in the world, the study of the image of the country of origin has attracted more and more attention from domestic scholars and enterprises. At present, the consumer research on the country of origin effect in China is still in its preliminary stage. Therefore, we hope that through this study, we can reveal the recognition of the country of origin image of the Chinese educated consumers represented by the contemporary college students, and the influence of the origin image on their purchasing intention. Firstly, this pater verifies the existence of the image effect of the country of origin. Secondly, this paper constructs the conceptual framework of the influence of the country of origin image on the purchase intention, introduces three dependent variables which are the country of origin image, product evaluation and purchase intention, and establishes and the relationship between the three. The results can provide guidance for enterprises to achieve more effective results in the promotion and communication by using origin attributes.

\section{Literature Review}

The "Harvard Business Review"(1962)wrote by Dichter pointed out that : "if phrases like "made in..." appear on the logo of the product, they may attract consumers' attention and have a huge impact on consumers' acceptance of products." With the rapid development of international trade, multinational corporations begin to emerge continuously, and the origin of products is subdivided into "manufacturing place", "design place" and "assembled place". Brand influence of multinational corporations is continuously strengthened, so some scholars believe that the brand image of an enterprise can affect the consumer's evaluation of product quality more than the design place or manufacturing place, so as to affect the purchasing tendency of consumers. The origin of the product is replaced by "brand origin", that is, the brand was bred and grown in that country at 
first. "Country of origin" in this paper means "brand origin". The brand origin image influences the consumer's evaluation of the brand, so as to affect the purchasing tendency of the consumer. We call this phenomenon "the country of origin effect".

Schooler(1965)believed that the image of the country of origin can be defined as a consumer's overall perception of the products produced in a country or region. This perception comes from consumers' impressions or feelings formed by a long time about the country's production and marketing.

Roth \& Romem (1992) further defined it as the consumers'overall perception of this country's products according to the past perceptions of consumers of the quality of a country's manufacturing capabilities and marketing capabilities. The country of origin effect is the impression of consumers on a country, and then the halo effect formed by consumers for this country's products.

\section{Theoretical Models and Hypotheses}

Theoretical Models. According to the relevant literature review, the study of consumers in different countries and regions shows that although the degree of change is different, the image effect of "country of origin" does exist among consumers. The image effect of the country of origin will really affect the consumers' evaluation and purchase desire of products, that is, under the same conditions, consumers will give different evaluations to the goods from different places of origin. These different evaluations lead to a shift in consumer buying intentions. However, two studies have shown that the effect of the image effect of the country of origin on consumers is not large. These two studies are made by SchleiferandDunn (1968), and Schooler and Sunoo (1969).It can be seen that the influence of the country of origin image on the purchase intention is mainly through the following two ways: The first one is that the country of origin image directly influences the purchase intention. The second one is that the origin image indirectly affects the purchase intention through the product evaluation and other intermediary variables. Therefore, the following hypothetical model can be established:

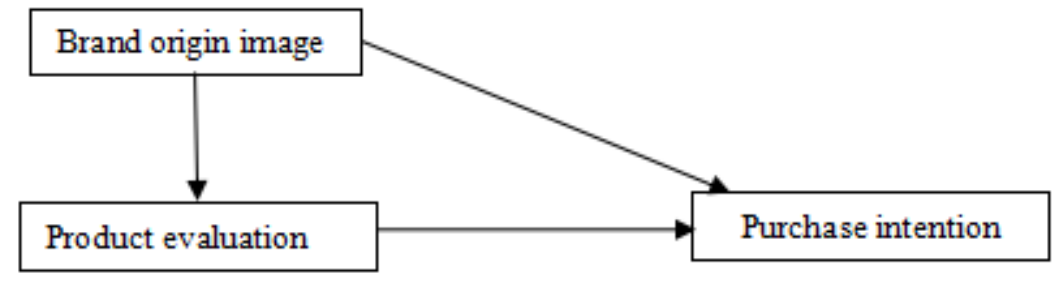

Figure 1.Theoretical model

Correlational Hypotheses. Studies have shown that Chinese consumers have a strong preference for foreign brands.(sin, 2000). One reason is that Chinese consumers' preference for foreign brands comes from the symbolic benefits that foreign brands bring to them. When consumers choose products, their cognitive process often includes the process of self cognition(Sirgy, 1991). That is to say, consumers tend to compare their desired image with the product's image. Products that are more compatible with the consumer's own image will be favored. Chinese consumers traditionally associate foreign brands with maturity, respectability, fashion(Simon, 2006). Therefore, Chinese consumers who eager to show these images are naturally more interested in foreign brands. Thus it can be seen that the domestic consumers often hope to display their own pursuit of personalized image through foreign brands. In this process, consumers are satisfied with the psychology of showing off and seeking approval. Therefore, the domestic consumers tend to choose the brand simply according to the image of the country of origin. Wright (1975) also believes that the concept of country of origin delivered to consumers is a holistic concept. It will directly affect consumers' purchasing intention of the brand, rather than always influence it through product attributes. So we put forward the hypothesis:

H1: The country of origin image in laptop student market has a direct impact on the purchase intention. 
$\mathrm{H} 2$ : The country of origin image in laptop student market has a direct impact on the product evaluation.

H3: The product evaluation in laptop student market has a direct impact on the purchase intention.

\section{Result Analysis}

This survey selected 300 students as samples. In the measurement of scale validity, the indicators used in this paper are AVE and CR value, and their acceptable critical values are 0.5 and 0.7 respectively. The specific results are shown in table 1. The factor load capacity is better than 0.4. For example, the factor load of media publicity performance of brand origin image in Mainland is 0.8. Then it shows that the media publicity performance plays a major role in the evaluation of brand origin image.

Table 1. Confirmatory factor analysis of variables

\begin{tabular}{|c|c|c|c|c|c|c|c|c|c|c|c|}
\hline \multirow[t]{2}{*}{ variable } & \multirow[t]{2}{*}{ Description } & \multicolumn{2}{|c|}{ Mainland } & \multicolumn{2}{|l|}{ Taiwan } & \multicolumn{2}{|l|}{ America } & \multicolumn{2}{|l|}{ Japan } & \multicolumn{2}{|l|}{ Korea } \\
\hline & & & $\begin{array}{l}\text { Stan } \\
\text { dard } \\
\text { fact } \\
\text { or } \\
\text { load } \\
\text { ing }\end{array}$ & & $\begin{array}{l}\text { Stan } \\
\text { dard } \\
\text { fact } \\
\text { or } \\
\text { load } \\
\text { ing }\end{array}$ & & $\begin{array}{l}\text { Stan } \\
\text { dard } \\
\text { fact } \\
\text { or } \\
\text { load } \\
\text { ing }\end{array}$ & & $\begin{array}{l}\text { Stan } \\
\text { dard } \\
\text { facto } \\
\text { r } \\
\text { loadi } \\
\text { ng }\end{array}$ & & $\begin{array}{l}\text { Stan } \\
\text { dard } \\
\text { facto } \\
\mathrm{r} \\
\text { loadi } \\
\mathrm{ng}\end{array}$ \\
\hline \multirow{4}{*}{$\begin{array}{l}\text { Brand } \\
\text { image of } \\
\text { country } \\
\text { of origin }\end{array}$} & $\begin{array}{l}\text { Media publicity } \\
\text { performance }\end{array}$ & \multirow{4}{*}{$\begin{array}{l}\alpha=0.697 \\
C R=0.68 \\
\text { AVE }=0 . \\
55\end{array}$} & 0.8 & \multirow{4}{*}{$\begin{array}{l}\alpha=0.670 \\
C R=0.67 \\
\text { AVE }=0 . \\
49\end{array}$} & 0.49 & \multirow{4}{*}{$\begin{array}{l}\alpha=0.696 \\
C R=0.69 \\
A V E=0 . \\
47\end{array}$} & 0.5 & \multirow{4}{*}{$\begin{array}{l}\alpha=0.754 \\
C R=0.68 \\
\text { AVE }=0 . \\
45\end{array}$} & 0.65 & \multirow{4}{*}{$\begin{array}{l}\alpha=0.735 \\
C R=0.7 \\
4 \\
\mathrm{AVE}=0 . \\
43\end{array}$} & 0.7 \\
\hline & $\begin{array}{l}\text { Degree of } \\
\text { trustworthiness }\end{array}$ & & 0.75 & & 0.58 & & 0.45 & & 0.58 & & 0.86 \\
\hline & $\begin{array}{l}\text { Level of } \\
\text { economic } \\
\text { development }\end{array}$ & & 0.51 & & 0.61 & & 0.7 & & 0.67 & & 0.55 \\
\hline & $\begin{array}{l}\text { Development } \\
\text { level of } \\
\text { electronic } \\
\text { communication }\end{array}$ & & 0.54 & & 0.65 & & 0.73 & & 0.74 & & 0.44 \\
\hline \multirow{7}{*}{$\begin{array}{c}\text { Product } \\
\text { evaluatio } \\
n\end{array}$} & $\begin{array}{l}\text { Sophisticated } \\
\text { technology }\end{array}$ & \multirow{7}{*}{$\begin{array}{l}\alpha=0.574 \\
C R=0.60 \\
A V E=0 . \\
56\end{array}$} & 0.73 & \multirow{7}{*}{$\begin{array}{l}\alpha=0.829 \\
C R=0.91 \\
A V E=0 . \\
56\end{array}$} & 0.72 & \multirow{7}{*}{$\begin{array}{l}\alpha=0.674 \\
C R=0.80 \\
A V E=0 . \\
55\end{array}$} & 0.7 & \multirow{7}{*}{$\begin{array}{l}\alpha=0.593 \\
C R=0.74 \\
\text { AVE }=0 . \\
51\end{array}$} & 0.12 & \multirow{7}{*}{$\begin{array}{l}\alpha=0.641 \\
\mathrm{CR}=0.9 \\
1 \\
\mathrm{AVE}=0 . \\
58\end{array}$} & 0.8 \\
\hline & $\begin{array}{l}\text { Color design } \\
\text { style }\end{array}$ & & 0.4 & & 0.74 & & 0.47 & & 0.71 & & 0.61 \\
\hline & $\begin{array}{l}\text { good value for } \\
\text { money }\end{array}$ & & 0.22 & & 0.58 & & 0.38 & & 0.26 & & 0.55 \\
\hline & $\begin{array}{l}\text { Using } \\
\text { leading-edge } \\
\text { technology }\end{array}$ & & 0.19 & & 0.75 & & 0.52 & & 0.73 & & 0.81 \\
\hline & $\begin{array}{l}\text { Good after-sales } \\
\text { service }\end{array}$ & & 0.46 & & 0.57 & & 0.32 & & 0.12 & & 0.56 \\
\hline & $\begin{array}{l}\text { High brand } \\
\text { awareness }\end{array}$ & & 0.06 & & 0.56 & & 0.55 & & 0.78 & & 0.71 \\
\hline & $\begin{array}{l}\text { public praise of } \\
\text { country of origin }\end{array}$ & & 0.4 & & 0.59 & & 0.45 & & 0.63 & & 0.58 \\
\hline $\begin{array}{l}\text { Purchase } \\
\text { intention }\end{array}$ & $\begin{array}{l}\text { The possibility } \\
\text { of buying a } \\
\text { laptop of country } \\
\text { of origin of a } \\
\text { brand }\end{array}$ & & & & & & & & & & \\
\hline
\end{tabular}

\section{Hypothesis Testing}

In order to test the hypotheses, we use the Baron and Kenny (1986) method to test it through a series of regression equations. First of all, the brand origin image is taken as the independent variable, and the purchase intention is taken as the dependent variable (equation 1). Then the brand origin image is taken as independent variable, and product evaluation is taken as dependent variable (equation 2). Finally, the purchase intention is taken as the dependent variable, and the brand origin image and product evaluation are taken as the independent variable to make the regression analysis 
(equation 3). If the effect of brand origin image in equation 3 is less than equation 1, it can be seen that the product evaluation plays an intermediary role. The test results are shown in table 3:

$$
\mathrm{PI}=\alpha_{0}+\alpha_{1} \mathrm{COOI}+\varepsilon_{1}(1)
$$

Table 2. Equation 1 regression analysis results

\begin{tabular}{|l|l|l|l|l|}
\hline & $\alpha_{1}$ & $\mathrm{R}^{2}$ & Adjustment $\mathrm{R}^{2}$ & F-value \\
\hline Mainland & $\begin{array}{c}0.448 \\
(6.603 * * *)\end{array}$ & 0.200 & 0.196 & $43.602 * * *$ \\
\hline Taiwan & $\begin{array}{c}0.299 \\
(4.140 * * *)\end{array}$ & 0.090 & 0.084 & $17.142 * * *$ \\
\hline America & $\begin{array}{c}0.366 \\
(5.186 * * *)\end{array}$ & 0.134 & 0.129 & $26.897 * * *$ \\
\hline Japan & $\begin{array}{c}0.306 \\
(4.232 * * *)\end{array}$ & 0.093 & 0.88 & $17.911 * * *$ \\
\hline Korea & $\begin{array}{c}0.371 \\
(5.251 * * *)\end{array}$ & 0.137 & 0.132 & $27.570 * * *$ \\
\hline
\end{tabular}

$$
\mathrm{PDEV}=\alpha_{0}{ }^{\natural}+\alpha_{2} \mathrm{COOI}+\varepsilon_{2}(2)
$$

Table 3. Equation 2 regression analysis results

\begin{tabular}{|l|l|l|l|l|}
\hline & $\alpha_{1}$ & $\mathrm{R}^{2}$ & Adjustment $\mathrm{R}^{2}$ & F-value \\
\hline Mainland & $\begin{array}{c}0.310 \\
(4.307 * * *)\end{array}$ & 0.096 & 0.196 & $43.602 * * *$ \\
\hline Taiwan & $\begin{array}{c}0.618 \\
(10.383 * * *)\end{array}$ & 0.383 & 0.091 & $107.800 * * *$ \\
\hline America & $\begin{array}{c}0.571 \\
(9.181 * * *)\end{array}$ & 0.326 & 0.379 & $84.285 * * *$ \\
\hline Japan & $\begin{array}{c}0.285 \\
(3.919 * * *)\end{array}$ & 0.081 & 0.322 & $15.356 * * *$ \\
\hline Korea & $\begin{array}{c}0.366 \\
(5.183 * * *)\end{array}$ & 0.134 & 0.076 & $26.862 * * *$ \\
\hline
\end{tabular}

$\mathrm{PI}=\alpha_{0} "{ }^{\prime}+\alpha_{3} \mathrm{COOI}+\alpha_{4} \mathrm{PDEV}+\varepsilon_{3}(3)$

Table 4. Equation 3 regression analysis results

\begin{tabular}{|l|l|l|l|l|l|}
\hline & $\alpha_{3}$ & $\alpha_{4}$ & $\mathrm{R}^{2}$ & Adjustment $\mathrm{R}^{2}$ & F-value \\
\hline Mainland & 0.438 & 0.032 & 0.201 & 0.192 & $21.797 * * *$ \\
& $(6.126 * * *)$ & $(0.441)$ & & & \\
\hline Taiwan & 0.120 & 0.163 & 0.142 & 0.132 & $14.285 * * *$ \\
& $(1.337 * * *)$ & $(2.90 * * *)$ & & & \\
\hline America & 0.312 & 0.094 & 0.140 & 0.130 & $14.066 * * *$ \\
& $(3.633 * * *)$ & $(1.097)$ & & & \\
\hline Japan & 0.241 & 0.226 & 0.140 & 0.130 & $14.129 * * *$ \\
& $(3.278 * * *)$ & $(3.078 * * *)$ & & & \\
\hline Korea & 0.392 & -0.060 & 0.141 & 0.131 & $14.064 * * *$ \\
& $(5.177 * * *)$ & $(-7.87)$ & & & \\
\hline
\end{tabular}

Among them, PI stands for the purchase intention, COOI represents the brand origin image, and the PDEV stands for the product evaluation. The results show that the brand origin image has significant influence on purchase intention, and the brand origin image has significant influence on product evaluation. In the first equation, PI is the purchase intention, which includes the variable of country of origin image, and you can see that the coefficient of country of origin image is between $0.3-0.448$. The second equation is the linear regression equation of product evaluation about country of origin image. The third is the equation of the purchase intention about country of origin image and product evaluation. Since the coefficient of country of origin image of the third equations is between $0.120-0.438$ and less than the coefficient of the first equation, it can be concluded that the original product image has little effect on the purchase intention. Then it can be determined that it is affected by the factor of product evaluation, and it can be explained that the product evaluation has 
played an intermediary role. But in equation 3, only brand product evaluations in Taiwan and Japan have significant impact on purchase intention. The role of brand origin image is not obviously small, so it can't prove that the product evaluation has intermediary effect. Therefore, the hypothesis 1 is established, the hypothesis 2 is also established, but the hypothesis 3 can't be proved.

\section{Conclusion}

The brand origin image has a significant influence on product evaluation and purchase decision. This study introduces three variables: product evaluation, country of origin image and purchase intention. Through the correlation analysis of the survey data, we can see that the country of origin image is significantly related to the product evaluation, and the country of origin image is also significantly related to the purchase intention. This shows that the brand origin image has a significant impact on product evaluation and purchase decisions. However, the impact of product evaluation on purchase intention is not significant, which shows that the brand origin image is an important factor to enhance consumer purchasing intention. Enterprises should vigorously strengthen the image construction of the brand origin, build better media publicity, improve their product quality and pay attention to consumer's word-of-mouth communication.

\section{References}

[1] Dzever S and Quester P: Country-of-origin Effects on Purchasing Agent's Product Perceptions: An Australian Perspective[J]. Industrial Marketing Management,1999, (28):165.

[2] Robert D. Schooler. Product Bias in the Central American Common Market [J]. Journal of Marketing Research, 1965, (4):394.

[3] S.B.Tian and Q.J.Chen: A review of research on the Country of Origin Images in international operation[J]. Foreign Economies and Management, 2004,(8) : 25 -29.(In Chinese)

[4] H.Z.Wang: Consumer Ethnocentrism - Chinese Positivism and Marketing Theory[M]. Economic management press, 2002.

[5] Nagashima.A: A comparison of Japanese and U.S Attitude toward Foreign Products[J]. Journal of Marketing, 1970, (1):68.

[6] Khachaturian, J.L. and Morganosky, M.A.(1990), "Quality Perceptions by Country of Origin,'International Journal of Retail \& Distribution Management, 18 (5), 21-30.

[7] Hong S I and Toner J F. Are there Gender Differences in the Use of Country-of-origin Information in the Evaluation of Products? [J]. Advances in Consumer Research,1989, 16: 468-476.

[8] H.Z.Wang: Country of Origin Effect and Its Managerial Implications to Chinese Companies in the Global Market Arena[J]. China Industrial Economy, 2002. 